\title{
EKSPRESI CYTOSOLIC ASPARTATE-SPECIFIC CYSTEINE PROTEASE-3 (CASPASE-3) PADA JARINGAN HATI RATTUS NORVEGICUS (WISTAR) SETELAH PEMBERIAN SUBKRONIK AFLATOKSIN B1 (AFB1)
}

\section{EXPRESSION OF CYTOSOLIC ASPARTATE-SPECIFIC CYSTEINE PROTEASE-3 (CASPASE-3) IN THE LIVER TISSUE OF RATTUS NORVEGICUS (WISTAR) FOLLOWING SUBCHRONIC ADMINISTRATION OF AFLATOXIN-B1 (AFB1)}

\author{
Indah Dina Maritha*, Supranowo**, Diana Lyrawati *** \\ * Program Studi Pendidikan Dokter Fakultas Kedokteran Unversitas Brawijaya Malang \\ ** Laboratorium Patologi Anatomi Fakultas Kedokteran Universitas Brawijaya Malang \\ *** Laboratorium Farmasi Fakultas Kedokteran Universitas Brawijaya / RSU dr. Saiful Anwar Malang.
}

\begin{abstract}
Aflatoksin $B_{1}\left(A F B_{1}\right)$ is one of the toxic agents produced by Aspergillus flavus that frequently contaminates foods not properly stored. AFB1 undergoes biotransformation which may result in the production of reactive oxygen species (ROS) hazardous to liver cells. Following a cascade of oxidative reaction, ROS will cause the mitochondria to release cytochrome $c$ which subsequently activates caspase-3, leading to apoptosis. In this present study we evaluated the effect of aflatoxin B1 on the expression of caspase-3 in the liver. AFB1 was administered per oral, at different dosage and length of exposure, subchronically. This study was carried out as a factorial designed experiment with two factors. The first was dosage factor i.e 0, 10, 15 and $20 \mu \mathrm{g}(0 ; 0,05 ; 0,075 ; 0,1 \mu \mathrm{g} / \mathrm{g} \mathrm{BW})$ and the second was exposure time factor i.e. 12, 16 and 20 weeks. Rattus norvegicus strain Wistar aged approximately eight weeks old and weighed 180-200 g were used as the experimental animals. The expression of caspase- 3 was examined by using immunohistochemistry. The results showed that the expression of caspase-3 increased significantly $(p=0,000)$ with the escalation of $A F B_{1}$ in dosage and/or exposure time $(p=0,001)$. In the interaction between dose and exposure time of $A F B_{1}$ an increase in the expression of caspase-3 was also observed $(p=0,000)$. Interestingly, these studies also revealed that in the liver tissues there was a limitation in the expression of caspase-3, where the raising of further AFB1 dosage and length of exposure were not followed by further increase of the caspase-3. The caspase-3 expression tends to decrease after the administration of AFB1 $20 \mathrm{ug}$ for 16 weeks. Microscopic observations demonstrated that the number of the liver cells was declining with the increasing dosage and length of exposure to AFB1. Combining those data, it can be concluded that reduction of caspase-3 following certain high dosage and length of exposure to AFB1 may be attributed to the loss of the majority of the liver cells due to apoptosis, thus only a small amount of the remaining liver cells could response and express caspase-3.
\end{abstract}

Key words: Aflatoxin B1; caspase-3; Rattus norvegicus; liver

\section{PENDAHULUAN}

Di Indonesia, aflatoksin merupakan mikotoksin yang sering ditemukan pada produk-produk pertanian dan hasil olahannya (1). Aflatoksin ini dihasilkan oleh jamur AspergiIlus flavus (2) menjadi salah satu masalah yang cukup signifikan terhadap kesehatan masyarakat (3). Umumnya, kondisi geografis tropis seperti di Indonesia, berupa: temperatur dan kelembaban tinggi, musim hujan yang turun tidak sesuai dengan musimnya saat panen, dan banjir yang datang tiba-tiba, mendukung terjadinya proliferasi jamur dan produksi mikotoksin. Teknik pemanenan yang salah, penyim-

Jurnal Kedokteran Brawijaya, Vol. XXII, No. 3, Desember 2006 Korespondensi: Diana Lyrawati; Laboratorium Farmasi FK Unibraw / RSU dr. Saiful Anwar Malang; Jl. Veteran Malang 65145; 0341 - 580993; email: eldi_7_98@yahoo.com panan yang tidak layak, dan kondisi yang kurang optimal saat transportasi dan pemasaran juga berkontribusi pada pertumbuhan jamur dan peningkatan resiko produksi mikotoksin (3).

Secara alami aflatoksin terdiri dari 4 komponen induk yaitu aflatoksin $B_{1}\left(A F B_{1}\right)$, aflatoksin $B_{2}\left(A F B_{2}\right)$, aflatoksin $G_{1}$ $\left(A F G_{1}\right)$, dan aflatoksin $G_{2}\left(A F G_{2}\right)$, namun aflatoksin $B_{1}$ $\left(\mathrm{AFB}_{1}\right)$ merupakan mayoritas dan yang paling toksik $(2,4)$. Salah satu dari banyak laporan menunjukkan bahwa aflatoksin $B_{1}$ ditemukan pada biji lada yang rusak yang banyak dikonsumsi masyarakat golongan bawah di Malang (1).

Di dalam tubuh AFB1 menimbulkan kerusakan pada bermacam-macam organ tubuh tetapi hati merupakan sasaran utama $(1,4)$. Aflatoksin $B_{1}$ menyebabkan terjadinya efek toksik pada berbagai organel dalam sel hati dan mengakibatkan berbagai jenis kerusakan hati seperti steatosis, ne- 
krosis, sirosis serta karsinogenesis (5). Metabolisme memainkan peranan penting dalam menentukan toksisitas $\mathrm{AFB}_{1}$. Penelitian menunjukkan bahwa aflatoksin membutuhkan aktivasi dari metabolisme untuk menyebabkan efek karsinogennya (4). Di dalam hati, $\mathrm{AFB}_{1}$ mengalami biotransformasi menjadi berbagai metabolit, diantaranya produk-produk senyawa oksigen reaktif. Dalam keadaan normal tanpa induksi, pembentukan senyawa oksigen reaktif akan diredam oleh antioksidan tubuh, tetapi bila induksi terus berlanjut, maka timbul suatu keadaan yang disebut stress oksidatif (1). Pada biotransformasi $\mathrm{AFB}_{1}$ proses oksidatif ini akan membentuk Reactive Oxygen Spesies (ROS) (1). Apabila hal ini terus berlanjut ROS akan menyebabkan mitokondria melepaskan sitokrom c yang akan menyebabkan teraktifasinya caspase-3 dan selanjutnya mencetuskan apoptosis $(1,6)$.

Cytosolic Aspartate-Specific Cysteine Proteases (caspase) adalah kelompok protease yang memfasilitasi terjadinya kematian sel (7). Salah satu dari famili ini adalah caspase-3 (CPP32, apopain, YAMA) yang telah terbukti sebagai mediator kunci proses apoptosis pada sel mamalia (8). Caspase berada dalam keadaan inaktif sampai salah satu caspase teraktivasi oleh suatu sinyal kemudian terjadi rangkaian reaksi (cascade) aktivasi caspase berikutnya melalui proses proteolitik (7).

Lama pemberian dan dosis AFB1 yang berbeda akan memberikan efek toksik yang berbeda terhadap sel hati (1). Efek toksik yang berbeda ini mungkin berkaitan dengan ROS yang dihasilkan dari biotransformasi oksidatif AFB1 yang terjadi pada sel hati sehingga diduga juga akan berakibat pada perubahan ekspresi caspase-3 dan berakhir dengan apoptosis. Dalam penelitian ini dipelajari efek pemberian AFB1 terhadap ekspresi caspase-3 sel hati, apakah kenaikan dosis dan lama pemberian AFB1 akan diikuti juga dengan peningkatan ekspresi caspase-3 sebagai salah satu respon pada sel hati. AFB1 diberikan secara peroral subkronik, menyesuaikan dengan jalan masuknya toksin ini pada kejadian yang sering dijumpai di masyarakat.

\section{METODE}

\section{Binatang coba}

Rattus norvegicus galur Wistar jantan, didapat dari Unit Pemeliharaan Hewan Percobaan Universitas Gajah Mada, Yogyakarta, berumur 2 bulan dengan berat badan 180-200 g. Tikus dipelihara dalam bak plastik yang ditutup dengan anyaman kawat beralaskan sekam. Setiap kelompok tikus untuk satu dosis AFB1 atau lama pemberian, masing-masing terdiri dari 3 ekor, ditempatkan dalam 1 kandang. Tikus diberi makanan dasar berupa butiran pelet yang mengandung protein, hidrat arang, serat, lemak, dan mineral dengan kandungan energi 2800-3000 kkal/kg dan air untuk minum. Seluruh prosedur perlakuan terhadap binatang dilakukan di dan berdasarkan persetujuan Komisi Animal Ethics Universitas Airlangga, Surabaya.

\section{Dosis dan lama pemberian AFB1}

Setelah melewati masa adaptasi 10 hari, tikus putih yang sudah dibagi atas 12 kelompok perlakuan mendapat perlakuan sesuai dengan rancangan percobaan. Rancangan percobaan yang digunakan adalah faktorial dengan 2 faktor yaitu faktor lama pemberian yang terdiri atas 3 tingkat yaitu 12, 16 dan 20 minggu dan faktor dosis pemberian yang terdiri atas 4 tingkat yaitu dosis AFB1 (Sigma) 0, 10, 15 dan $20 \mu \mathrm{g} /$ hari atau 0; 0,05; 0,075; 0,1 $\mu \mathrm{g} / \mathrm{g}$ BB sekali sehari peroral. Berdasarkan penelitian sebelumnya diketahui bahwa dengan pewarnaan HE pada sediaan histopatologi sel hati dari tikus yang mendapat $\mathrm{AFB}_{1} 15 \mu \mathrm{g}$ selama 16 minggu ditemukan adanya lesi preneoplastik (altered foci) (9). Pada penelitian ini efek terhadap caspase-3 diteliti pada rentang dosis $\mathrm{AFB}_{1}$ kurang dari dan lebih dari $15 \mu \mathrm{g}$ serta lama pemberian sebelum dan sesudah 16 minggu.

Pada akhir periode, yaitu setelah 12, 16 atau 20 minggu, tikus puth dimatikan dengan cara cervix dislocation, organ hati kemudian diambil dan dimasukkan ke dalam sukrosa $0,25 \mathrm{M}$ suhu $4^{\circ} \mathrm{C}$ untuk dibuat sediaan histologi.

\section{Deteksi caspase-3}

Sebagian hati digunakan untuk sediaan histologi dengan metode parafin tanpa pewarnaan $\mathrm{HE}$, kemudian untuk pemeriksaan caspase-3 digunakan prosedur standar pewarnaan imunohistokimia (10). Antibodi primer yang digunakan adalah antibodi poliklonal caspase-3 (rabbit polyclonal anti-mouse caspase-3, (Dako), antibodi sekunder anti rabbit biotin conjugated (Dako). Ekspresi caspase-3 dilihat secara mikroskopis yaitu dengan mengamati pewarnaan kecoklatan karena dari reaksi antibodi anti caspase-3 yang divisualisasi dengan oleh kromogen DAB (Sigma). Dilakukan tiga pengulangan untuk tiap perlakuan pada percobaan ini. Penghitungan dengan menggunakan mikroskop cahaya (Olympus) pada 20 lapangan pandang dengan perbesaran 1000 kali. Jumlah ekspresi caspase-3 dihitung dengan cara menghitung jumlah sel hati yang menunjukkan pewarnaan kecoklatan.

\section{Analisis statistik}

Data yang diperoleh dianalisis menggunakan univariate analysis of variance, analisis ragam lanjut dan Tukey HSD.

\section{HASIL PENELITIAN}

Pada pemberian $\mathrm{AFB}_{1}$ terlihat bahwa jumlah sel hati yang mengekspresikan caspase-3 akan meningkat seiring dengan peningkatan dosis dan lama pemberian $\mathrm{AFB}_{1}$ sampai batas tertentu (lihat Gambar 1), tetapi setelah itu akan mengalami penurunan (pemberian $\mathrm{AFB}_{1} 20 \mu \mathrm{g}$ selama 16 minggu). 
Pengujian kemaknaan pengaruh $\mathrm{AFB}_{1}$ berdasarkan dosis dan lama serta interaksi dosis dan lama pemberian $\mathrm{AFB}_{1}$ terhadap peningkatan ekspresi caspase-3 jaringan hati tikus putih dilakukan dengan uji univariate analysis of variance. Hasil univariate analysis of variance menunjukkan $\mathrm{p}$-value $<\mathrm{a}(0,05)$, sehingga $\mathrm{H}_{0}$ ditolak atau dengan kata lain terdapat pengaruh yang bermakna antara dosis dan lama pemberian serta interaksi dosis dan lama pemberian $\mathrm{AFB}_{1}$ terhadap peningkatan jumlah ekspresi caspase-3 dalam jaringan hati tikus putih.

Univariate analysis of variance pada percobaan ini juga menunjukkan bahwa pemberian beberapa dosis $\mathrm{AFB}_{1}$ pada tikus percobaan dapat meningkatkan ekspresi caspase-3 secara signifikan $(p=0,000)$. Ditinjau dari pengaruh lama pemberian $\mathrm{AFB}_{1}$ terhadap ekspresi caspase-3 terlihat juga bahwa lama pemberian $\mathrm{AFB}_{1}$ yang berbeda dapat meningkatkan ekspresi Caspase-3 secara signifikan $(p=0,001)$. Pemberian $\mathrm{AFB}_{1}$ dengan lama pemberian 12 minggu, 16 minggu, dan 20 minggu dapat meningkatkan ekspresi Caspase-3 secara signifikan (Fhit > Ftabel).

Untuk mengetahui kemaknaan perbedaan sel hati yang mengekspresikan caspase-3 berdasarkan dosis, lama pemberian, interaksi dosis dan lama pemberian dilakukan uji Tukey HSD. Hasil uji menunjukkan bahwa dibandingkan dengan kontrol tanpa perlakuan, jumlah ekspresi caspase-3 jaringan hati tikus putih meningkat bermakna pada semua kelompok tikus putih yang mendapatkan $\mathrm{AFB}_{1}$ pada semua kombinasi dosis dan lama pemberian $(p=0,000)$.

\section{Ekspresi caspase-3 setelah induksi aflatoksin}

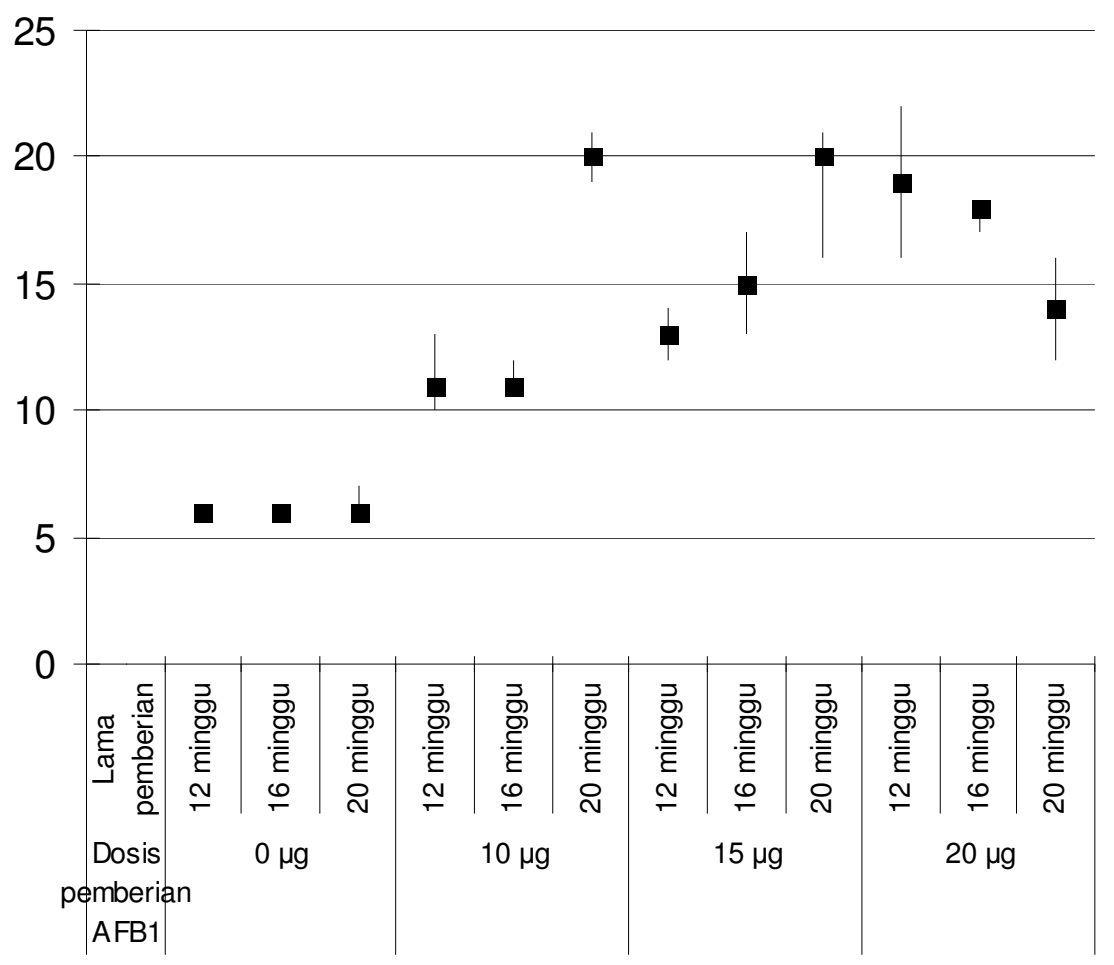

Gambar 1.Nilai Rerata Ekspresi Caspase-3 Jaringan Hati Tikus Putih Akibat Pemberian AFB $_{1}$ pada Beberapa Dosis dan Lama Pemberian. Grafik menunjukkan jumlah sel yang mengekspresikan caspase-3 per lapang pandang ( $Y$ axis). Pemberian aflatoksin B1 menunjukkan peningkatan ekspresi caspase-3. Peningkatan tersebut tergantung dosis dan lama pemberian aflatoksin B1. 

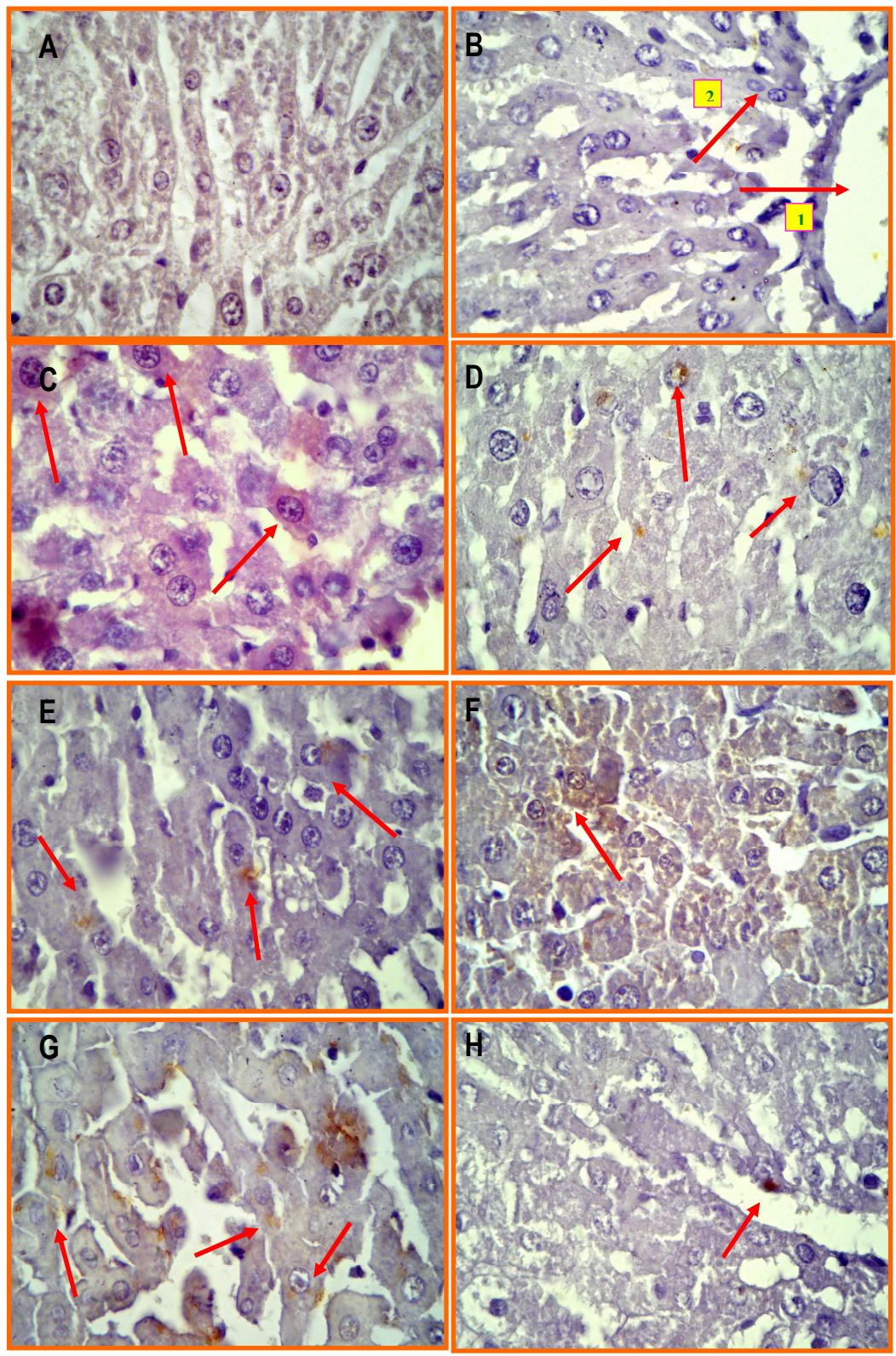

Gambar 2. Pengamatan Imunohistokimia Caspase-3 dan Jumlah Sel pada Jaringan Hati.

A. Kontrol imunohistokimia tanpa antibodi primer, B. Kontrol $0 \mu \mathrm{g} / \mathrm{hari}$ AFB1, C. $10 \mu \mathrm{g} / \mathrm{hari}$ AFB1 $12 \mathrm{minggu}, \mathrm{D}-\mathrm{F} 15 \mu \mathrm{g} / \mathrm{hari}$ AFB1 12, 16 dan 20 minggu, G-H. 20 mg/hari AFB1 16-20 minggu. Tanda panah menunjukkan pewarnaan kecoklatan dari caspase-3.

Selain caspase-3, juga diamati jumlah sel hati setelah tikus mendapat AFB1. Pengamatan mikroskopis ini menunjukkan adanya penurunan jumlah sel hati seiring dengan peningkatan dosis dan lama pemberian AFB1 (Gambar 2). Nampak bahwa jumlah sel hati setelah pemberian 20 $\mu \mathrm{g} / \mathrm{hari}$ AFB1 selama 20 minggu lebih sedikit dibanding kontrol tanpa perlakuan atau yang mendapat AFB1 dosis lebih lecil dan periode lebih singkat.
DISKUSI

Secara umum dapat dikatakan bahwa peningkatan dosis dan/atau lama pemberian AFB1 berasosiasi dengan peningkatan caspase-3, namun seperti yang terlihat pada Gambar 1, peningkatan caspase-3 ini tidak selalu linier sejalan dengan peningkatan dosis dan lama pemberian AFB1.

Sebaliknya, dalam penelitian ini dapat diamati adanya batas ekspresi caspase-3, di mana peningkatan lebih lanjut dari dosis dan lama pemberian tidak lagi diikuti dengan peningkatan ekspresi caspase-3 pada jaringan hati yang diamati. Kecenderungan penurunan ekspresi caspase- 
3 mulai terlihat setelah pemberian $\mathrm{AFB}_{1} 20 \mu \mathrm{g}$ selama 16 minggu.

Secara teoritis dan dari hasil penelitian lain (1) pemberian $\mathrm{AFB}_{1}$ akan semakin meningkatkan pembentukan $\mathrm{O}_{2}{ }^{0-}$ dan $\mathrm{H}_{2} \mathrm{O}_{2}$ akibat proses oksidatif pada biotransformasi $\mathrm{AFB}_{1}$ oleh sitokrom P-450. Hal ini menyebabkan semakin banyaknya enzim SOD dan katalase jaringan hati tikus putih yang terkuras untuk menetralisir $\mathrm{O}_{2}{ }^{0-}$ dan $\mathrm{H}_{2} \mathrm{O}_{2}$ yang terbentuk, sehingga aktivitas enzim ini semakin lama semakin menurun dan jumlah $\mathrm{OH}^{0}$ yang terbentuk akan semakin meningkat. Dengan meningkatnya jumlah $\mathrm{OH}^{0}$, maka porus mitokondria pada sel yang dipapar stres oksidatif yang kuat akan terbuka, sitokrom c keluar dan mengaktivasi caspase- 3 untuk memulai proses apoptosis dan ekspresi caspase-3 juga akan semakin meningkat. Sedangkan penurunan jumlah ekspresi caspase-3 diduga karena sudah terjadi ketidakmampuan jaringan untuk melakukan proses apoptosis.

Naik turunnya ekspresi caspase-3 yang tergantung pada dosis dan lama pemberian AFB1 dapat juga dijelaskan sebagai berikut. Pengamatan mikroskopis menunjukkan adanya penurunan jumlah sel hati seiring dengan peningkatan dosis dan lama pemberian AFB1 (Gambar 2). Nampak bahwa jumlah sel hati setelah pemberian 20 $\mu \mathrm{g} /$ hari AFB1 selama 20 minggu lebih sedikit dibanding kontrol tanpa perlakuan atau yang mendapat AFB1 dosis lebih lecil dan periode lebih singkat. Hal tersebut dapat dijelaskan bahwa sebagai respon terhadap peningkatan dosis AFB1 dan atau lama pemberian, sel hati akan mengekspresikan caspase-3 dengan jumlah yang awalnya secara kumulatif meningkat bermakna. Caspase-3 ini diketahui mengakibatkan apoptosis, sehingga peningkatan caspase-3 dapat berarti juga peningkatan apoptosis. Jika batas tertentu (threshold level) terlampaui, yaitu keadaan di mana apoptosis sudah sedemikian parah, menyisakan sangat sedikit (atau ahkirnya bahkan tidak ada lagi) sel hati yang masih bisa merespon AFB1 maka pada peningkatan paparan AFB1, baik dosis dan atau lama pemberian, maka tidak mengejutkan jika pola yang terlihat selanjutnya adalah penurunan ekspresi caspase-3.

Pada penelitian ini fenomena naik-turunnya serta batas ekspresi caspase-3 terlihat jelas (Gambar 1). Mengkombinasikan data ekspresi caspase-3 dan hasil pengamatan mikroskopis jumlah sel hati (Gambar 2) maka penurunan caspase-3 setelah dosis dan lama pemberian tertentu besar kemungkinan karena sebagian besar sel hati sudah mengalami apoptosis sehingga jumlah sel hati yang mampu mengekspresikan caspase-3 sudah tidak banyak lagi. Oleh karena itu, pada kondisi ini, secara kumulatif pada jaringan hati, ekspresi caspase-3 akan berkurang.

\section{KESIMPULAN DAN SARAN}

Pemberian AFB1 peroral pada Rattus norvegicus jantan secara terus menerus berasosiasi dengan perubahan ekspresi caspase-3 pada jaringan hati, mula-mula meningkat kemudian menurun. Sebagai respon terhadap AFB1, sel hati akan mengekspresikan caspase-3 dengan jumlah yang awalnya secara kumulatif meningkat bermakna sesuai dengan peningkatan dosis dan atau lama pemberian AFB1. Karena caspase-3 ini diketahui mengakibatkan apoptosis, maka peningkatan caspase-3 dapat berarti juga peningkatan apoptosis, sehingga jumlah sel hati juga akan menurun. Sampai batas tertentu (threshold level) terlampaui, di mana apoptosis sudah sedemikian parah, sehingga sel hati yang masih bisa merespon AFB1 sangat sedikit, maka peningkatan paparan AFB1, baik dosis dan atau lama pemberian akan berasosiasi dengan pola ekspresi caspase-3 yang menurun. Untuk klarifikasi apakah memang hanya apoptosis yang menyebabkan sel hati berkurang, dan apakah caspase-3 ini sebenarnya melindungi sel hati terhadap AFB1 atau sebaliknya mengakibatkan kerusakan hati sampai hepatokarsinoma, masih diperlukan penelitian yang lebih lanjut.

\section{DAFTAR KEPUSTAKAAN}

1. Yanwirasti. Kajian Biologi Molekuler pada Kerusakan Sel Hati Sebagai Akibat Proses Oksidatif Biotransformasi AFB;: Suatu Eksperimental Murni Laboratorium pada Tikus Putih (Rattus norvegicus). [Disertasi]. Tidak diterbitkan, Surabaya: Program Pasca Sarjana Universitas Airlangga. 2004

2. Makfoeld D. Mikotoksin Pangan. Yogyakarta: Penerbit Kanisius; 1993; 26-91.

3. WHO. Fact Sheet $5^{0}$ : Mycotoxins. Office of Information South Africa, 1999; 1-2.

4. CFSAN. Aflatoxins. 1998 (Online), (http://vm.cfsan. fda.gov/ mow/ chap41.html, diakses tanggal 15 Oktober 2004).

5. World Health Organization. IARC Monograps on the Evaluation of Carcinogenic Risk to Human International Agency for Research on Cancer . 1993; 56 : 268.

6. Kimball JW. Apoptosis. 2004. (Online), (http://users.ren.com/jkimball. ma.ultranet/BiologyPages/A/Apoptosis. htmlprot, diakses tanggal 5 Mei 2006).

7. Rndsystem. Apoptosis: Caspase Pathways. 2004. (http://www.rndsystem. com/asp/b index.asp?ArticlelD=22, diakses tanggal 27 Oktober 2004). 
8. Kothakota S, Azuma T, Reinhard C, Klippel A, Tang J, Chu K, McGarry TJ, Kirschner MW, Koths K, Kwiatkowski DJ, Williams LT. Caspase 3-generated fragment of gelsolin: effector of morphological change in apoptosis. Science 1997; 278 (5336): 294-298.

9. Lestariana W. Pengaruh Kandungan Vitamin A dalam Ransum terhadap Efek Toksik Aflatoksin B1 pada Tikus Putih (Rattus norvegicus). [Disertasi]. Tidak diterbitkan, Yogyakarta: Universitas Gajah Mada. 1997

10. Pizem J, Cor A. Review : Detection of Apoptotic Cells in Tumor Paraffin Section. Slovenia: Institute of Pathology and Institute for Histology and Embryoloy Medical Faculty Ljubljana; 2003; 37 (4): 225-232. 